Journal of Applied Pharmaceutical Science Vol. 5 (05), pp. 075-079, May, 2015

Available online at http://www.japsonline.com

DOI: $10.7324 / \mathrm{JAPS} .2015 .50514$

ISSN 2231-3354 (cc) BY-NC-SA

\title{
Antithrombotic activities of Newbouldia laevis (P. Beauv) seem. ex Bureau leaves
}

\author{
Chinaka O. Nwaehujor ${ }^{1}$, Rita I. Udegbunam ${ }^{2}$, Julius O. Ode ${ }^{3}$, Stella A. Madubuike ${ }^{4}$ \\ ${ }^{1}$ Department of Biochemistry, Faculty of Basic Medical Sciences, University of Calabar, P.M.B. 1115 Calabar, Nigeria. \\ ${ }^{2}$ Department of Veterinary Surgery, Faculty of Veterinary Medicine, University of Nigeria, Nsukka, Nigeria. \\ ${ }^{3}$ Department of Veterinary Pharmacology and Toxicology, Faculty of Veterinary Medicine, University of Abuja, P.M.B. 117 Abuja, Nigeria. \\ ${ }^{4}$ Department of Veterinary Microbiology, Faculty of Veterinary Medicine, Ahmadu Bello University, Zaria, Nigeria.
}

\begin{tabular}{|c|c|}
\hline ARTICLE INFO & ABSTRACT \\
\hline Article history: & \multirow{12}{*}{$\begin{array}{l}\text { The study evaluated anticoagulant properties of the methanol extract of Newbouldia laevis leaves using blood } \\
\text { clotting time, bleeding time and thrombin-induced clotting assay as standard procedures. Oral acute toxicity } \\
\text { studies showed that the extract had a high safety margin, up to } 2000 \mathrm{mg} / \mathrm{kg} \text { in Wistar rats. The methanol leaf } \\
\text { extract of } N \text {. laevis significantly }(\mathrm{p}<0.05) \text { prolonged blood clotting times from the baseline value of } 11.0 \pm 0.6 \mathrm{~s} \\
\text { for the blood sample to } 18.0 \pm 0.7 \mathrm{~s} \text { and } 32.0 \pm 1.0 \mathrm{~s} \text { at } 5 \% \text { and } 10 \% \text { concentrations respectively. The crude } \\
\text { extract also exhibited appreciable in vivo and in vitro anticoagulant potency. High doses of the extract were most } \\
\text { significant }(\mathrm{p}<0.01) \text { in inducing rabbit bleeding which became prolonged to } 55.8 \pm 1.4 \mathrm{~s} \text { and } 73.1 \pm 0.8 \mathrm{~s} \text { at } 100 \\
\text { and } 200 \mathrm{mg} / \mathrm{kg} \text { respectively compared to the baseline }(18.0 \pm 0.2 \mathrm{~s}) \text { and effects of the reference anticoagulants. } \\
\text { Aspirin was found to have produced bleeding intervals of } 47.0 \pm 0.3 \mathrm{~s} \text { and } 70.1 \pm 0.2 \mathrm{~s} \text { at } 1.0 \text { and } 2.0 \mathrm{mg} / \mathrm{kg} \text { while } \\
\text { heparin }(0.75 \text { and } 1.5 \mathrm{mg} / \mathrm{kg} \text { ) induced bleeding times of } 41.6 \pm 0.8 \mathrm{~s} \text { and } 61.0 \pm 1.7 \mathrm{~s} \text { respectively. The vehicle } \\
\text { (distilled water) induced a transient baseline bleeding time of } 18.0 \pm 0.2 \mathrm{~s} \text {. However, the leaf extract of } N \text {. laevis } \\
\text { also potentiated elevation in thrombin-induced clotting time in a dose dependent manner but at a reduced potency } \\
\text { compared to heparin. Phytochemical analysis revealed the presence of reducing sugars, alkaloids, tannins, } \\
\text { flavonoids, resin, phenols, proteins and acid compounds in the crude extract. The results demonstrated that the } \\
\text { methanol leaf extract of } N \text {. laevis possesses pharmacologically active anticoagulant principles that could be } \\
\text { isolated and evaluated for clinical or physiological purposes. }\end{array}$} \\
\hline$/ 01 / 2015$ & \\
\hline $\mathrm{Re}$ & \\
\hline & \\
\hline Available online: $27 / 05 / 2015$ & \\
\hline Key words: & \\
\hline Anticoagulant, Newbouldia & \\
\hline laevis, Heparin, & \\
\hline Ethylenediaminetetraacetic & \\
\hline (EDTA), Thrombosis, & \\
\hline Thrombin-induced clotting & \\
\hline & \\
\hline
\end{tabular}

\section{INTRODUCTION}

Anti-thrombotics include anticoagulants, anti-platelets and thrombolytics that decrease the rate of blood clotting in the body by dissolving already formed ones or prevent clot formation (Webster, 2001). Most of the synthetic agents including heparin, non-steroidal anti-inflammatory drugs (e.g. aspirin), warfarin, ethylenediaminetetraacetic acid (EDTA), and citrate have been found valuable in preservation of blood samples, management of heart attacks and other complications of cardiovascular disorders (Handoll et al., 2002; Tohgi et al., 1992., McCardel et al., 1990). Anticoagulants are particularly indicated for strokes, transient ischaemic attacks, deep vein thrombosis and pulmonary embolism (Holbrook et al., 2005).

\footnotetext{
* Corresponding Author

Chinaka O. Nwaehujor, Department of Biochemistry, Faculty of Basic Medical Sciences, University of Calabar, P.M.B. 1115 Calabar, Nigeria.

Email: chinaka_n@yahoo.com
}

Oral anticoagulants have been used in the management of atherothrombotic stroke treatment (Donnan et al., 2008) which accounts for $61 \%$ of all strokes and have been relied upon for prevention and treatment for several decades. Physiological anticoagulants like heparin are not known to exert maximal preservative property on whole blood because its anticoagulant potentials are readily neutralized in plasma (Cheesbrough, 2000). EDTA is adjudged to be toxic to platelets and generally considered unsafe to be used in preserving blood for transfusion (Forscher et al., 1985).

Progressive cellular degeneration with compromised haematological profiles have been acknowledged over time in stored whole blood with various synthetic anticoagulants (Ahmed and Orakah, 2009; Lipp et al., 2005). This development underscores the rationale to exploit for a novel anticoagulant with physiological and therapeutic activities. Over the past decade, natural products derived from plant sources have proved to be useful sources of 'lead compounds' and new therapeutic agents. 
Some herbal plants including Zingiber officiale, Ginkgo biloba, Allium sativum, Panax ginseng and Synclisia scabrida have been studied and found to have marked anticoagulant properties (Afonne et al., 2000; Tattelman, 2005; Mousa, 2010). Newbouldia laevis commonly called African border tree or boundary tree is known locally as Aduruku in Hausa, Ogirisi in Igbo and Akoko in Yoruba languages of Northern, Eastern and Western Nigeria, respectively.

The plant is valued for many medicinal properties in various African tropical catalogues. Extracts from different parts of the plant (leaves, stem bark and roots) have been shown to possess antimicrobial, anti-malarial, antioxidant, nociceptive and anti-inflammatory properties (Gofner et al., 1997; Akunyili, 2000). The aqueous and ethanol leaf extracts displayed uterine contractile effects (Bafor and Sanni, 2009).

Preparation from the plant leaves is popular and highly acclaimed locally for anticoagulant effects among other healing activities by traditionalists in Ovoko community, Nsukka Local Government Area (L.G.A), Enugu State, Nigeria. The plant is considered sacred and used as a symbolic marker for sacred spots by the Yoruba tribe of Western, Nigeria. The present study sought to investigate the anticoagulant activities of $N$. laevis leaves using standard experimental models.

\section{MATERIALS AND METHODS}

\section{Experimental animals}

Matured inbred albino rats of both sexes weighing between 80-190 $\mathrm{g}$ and locally bred rabbits (2.0-2.2 $\mathrm{kg}$ ) were obtained from the Laboratory Animal Unit of the Department of Biochemistry, Faculty of Basic Medical Sciences, University of Calabar, Nigeria.

The animals were kept in different cages in the same room with a temperature varying between 28 and $30{ }^{\circ} \mathrm{C}$; lighting period was between 15 and $17 \mathrm{~h}$ daily. The rats were kept in stainless steel wire mesh cages which separated them from their faeces to prevent coprophagy. They were supplied clean drinking water and fed standard feed (Grower mash pellets, Vital feeds ${ }^{\circ}$, Nigeria). Rabbits were given fresh forages ad libitum. The animals were allowed two weeks to acclimatize prior to commencement of the experiments.

The use of the animals for experimentation complied with the 'Principles of Laboratory Animal Care' (NIH publication No. 85-23, revised 1985); all experiments were subjected to assessment and approval by the Laboratory Animal Ethics Committee of the University of Calabar, Nigeria and also in conformity with the standard guidelines of Helsinki Declaration, 1964.

\section{Plant Materials and Extraction}

Fresh leaves of Newbouldia laevis were collected from Ovoko community, Nsukka L.G.A. of Enugu State, Eastern Nigeria in April, 2011. The plant material was identified by Mr. A. O. Ozioko, a taxonomist with International Centre for
Ethnomedicine and Drug Development (InterCEDD) Nsukka, Enugu State, Nigeria. The leaves were dried at room temperature and pulverized into coarse powder using hammer mill. A $500 \mathrm{~g}$ of the powdered leaves was extracted by cold maceration in $80 \%$ methanol with intermittent and vigorous shaking every $2 \mathrm{~h}$ for 48 h. The extract was filtered with Whatman No. 1 filter paper; the filtrate concentrated in vacuo at $40{ }^{\circ} \mathrm{C}$ to dryness with a rotary evaporator, was denoted as Newbouldia laevis methanol leaf extract (NLMLE). The concentration and percentage yield of the extract were determined.

\section{Phytochemical analysis}

Tests for the presence of alkaloids, flavonoids, tannins, phenols, carbohydrates (Roopashree et al., 2008), reducing sugars, resin (Mushore and Matuvhumye, 2013), proteins (Fenk et al., 2007) and acidic compounds were conducted based on standard procedures (Trease and Evans, 1989).

\section{Acute toxicity test}

Thirty (30) matured albino rats of both sexes were weighed and randomly allocated to 5 groups (A-E) of 6 rats per group. Groups A-D were administered varying oral doses (300, 600,1000 , and $2000 \mathrm{mg} / \mathrm{kg}$ ) of the leaf extract (NLMLE), respectively but group $\mathrm{E}\left(5^{\text {th }}\right.$ group) was given an equivalent volume of distilled water $(10 \mathrm{ml} / \mathrm{kg})$. The rats, allowed access to feed and water ad libitum were observed for signs of toxicity and death for $72 \mathrm{~h}$.

\section{Blood clotting time}

The ability of $N$. laevis extract to inhibit in vitro coagulation of blood was quantitatively assayed following a standard procedure adopted by Koffuor and Amoateng (2011). Briefly, $1.0 \mathrm{ml}$ of whole blood drawn from the marginal ear vein of rabbits was added separately to $0.2 \mathrm{ml}$ of $5 \%$ and $10 \% \mathrm{w} / \mathrm{v}$ of NLMLE in test tubes placed in a water bath at $37{ }^{\circ} \mathrm{C}$. The time taken for the blood to clot in the separate concentration of the extract was recorded.

A repeat of each test was performed to obtain five determinants in coagulation times exerted with differences in concentration of the extract. Controls were coagulation time for blood in $0.2 \mathrm{ml}$ distilled water or blood alone as baseline clotting times.

\section{Rabbit bleeding time}

In vivo anticoagulant activity of $N$. laevis leaf extract was investigated as described by Elg et al. (2001). Rabbits were pretreated orally with 100 and $200 \mathrm{mg} / \mathrm{kg}$ of the extract and then allowed $30 \mathrm{~min}$. before pricking a small vein in the margin of the ear to induce bleeding.

The site of bleeding was gently blotted with filter paper every $5 \mathrm{~s}$. till cessation of bleeding (no bleeding for $60 \mathrm{~s}$ ). The observation time was limited to $10 \mathrm{~min}$. Care was taken that no pressure was exerted on the ear tips that could affect homeostasis. The above procedure was repeated using heparin $(0.75$ and 1.5 
$\mathrm{mg} / \mathrm{kg}$ ), aspirin (1 and $2 \mathrm{mg} / \mathrm{kg}$ ) and distilled water, respectively. A baseline bleeding time was already determined before any drug administration. Five determinations were taken after which a mean bleeding time for each treatment was obtained and compared.

\section{Thrombin-induced clotting time assay (TT)}

This assay measures the prolongation of thrombin generation. When human plasma is incubated with a compound which inhibits blood coagulation, the time taken for clot formation will be prolonged compared to the control (test devoid of inhibitor). In this assay, $200 \mu \mathrm{l}$ of human plasma (pre-incubated at $37{ }^{\circ} \mathrm{C}$ for $5 \mathrm{~min}$ before use) was incubated with different concentrations $(10,100$ and $1000 \mu \mathrm{g} / \mathrm{ml})$ of the extract for $5 \mathrm{~min}$ at $37{ }^{\circ} \mathrm{C}$; buffer and normal plasma served as the controls. Replicated concentrations (10, 100 and $1000 \mu \mathrm{g} / \mathrm{ml})$ of heparin were used as the reference anticoagulant. A fixed concentration $(100 \mu \mathrm{l})$ of bovine thrombin $(2.5 \mathrm{U} / \mathrm{ml}$, Sigma) was added to each sample to initiate reaction.

The time for clot formation was recorded accordingly (Dong et al., 1998). Results were expressed as a prolongation time relative to controls.

\section{Data analysis}

All data were expressed as Mean \pm SEM. Data were analyzed using one way analysis of variance (ANOVA) with Dunnet's test as the post hoc. Mean differences among treatment groups at $\mathrm{p}<0.5$ was considered significant.

\section{RESULTS}

\section{Description of the extract}

The methanol extract of Newbouldia laevis leaves was light greenish brown in colour with no peculiar odour. The extraction process gave a yield of $13.47 \% \mathrm{w} / \mathrm{w}$.

\section{Phytochemical analysis}

The results revealed the presence of alkaloids, reducing sugars, tannins, flavonoids, resins, phenols, proteins and acidic compounds in the crude methanol extract of $N$. laevis leaves.

\section{Acute toxicity studies}

Oral acute toxicity studies showed that the methanol leaf extract of $N$. laevis did not cause mortality or overt pathological lesions in the experimental rats even at the highest test dose $(2000$ $\mathrm{mg} / \mathrm{kg}$ ) within $72 \mathrm{~h}$ of the investigation. The rats moved freely, fed normally with no deviation in the consistency of the droppings relative to the control.

\section{Blood clotting time}

Blood clotting times with $5 \%$ and $10 \% \mathrm{w} / \mathrm{v}$ of extract (NLMLE) were significantly $(\mathrm{p}<0.05)$ prolonged compared to control values with distilled water or blood alone. The higher concentration $(10 \%)$ of extract induced the sampled blood to clot at $32.00 \pm 1.0 \mathrm{~s} ; 5 \%$ extract produced a mean blood clotting time of $18.00 \pm 0.7 \mathrm{~s}$ while distilled water or blood alone produced clotting within a limited of $11.00 \pm 0.4 \mathrm{~s}$ and $7.00 \pm 0.6 \mathrm{~s}$ respectively (Table 1 ).

Table 1: In vitro effects of $5 \%$ and $10 \%$ Newbouldia laevis methanol leaf extract on rabbit blood clotting time.

\begin{tabular}{ll}
\hline Concentration & Mean Clotting time (s) \\
\hline Blood alone & $7.00 \pm 0.6$ \\
Blood + distilled water & $11.00 \pm 0.4$ \\
Blood $+5 \%$ extract (NLMLE) & $18.00 \pm 0.7 *$ \\
Blood + $10 \%$ extract (NLMLE) & $32.00 \pm 1.0 *$ \\
\hline
\end{tabular}

Values are mean \pm SEM $(n=5) ; * p<0.05$ compared to control groups; NLMLE $=$ Newbouldia laevis methanol leaf extract

\section{Rabbit bleeding time}

The duration of bleeding in rabbits treated with 100 and $200 \mathrm{mg} / \mathrm{kg}$ of $N$. laevis extract was found to have significantly ( $\mathrm{p}<$ 0.01 ) increased to $55.8 \pm 1.4 \mathrm{~s}$ and $73.1 \pm 0.8 \mathrm{~s}$ respectively from the baseline bleeding time of $18.0 \pm 0.2 \mathrm{~s}$ produced by the vehicle (distilled water).

Aspirin also induced increased bleeding time values of $47.0 \pm 0.3 \mathrm{~s}$ and $70.1 \pm 0.2 \mathrm{~s}$ at 1.0 and $2.0 \mathrm{mg} / \mathrm{kg}$ while heparin caused the same effect (bleeding) for $41.6 \pm 0.8 \mathrm{~s}$ and $61.0 \pm 1.7 \mathrm{~s}$ at 0.75 and $1.5 \mathrm{mg} / \mathrm{kg}$ respectively (Fig. 1). Even though, the bleeding times produced with the doses of extract became prolonged, there was no significant $(p>0.05)$ difference in the effects with those of aspirin or heparin.

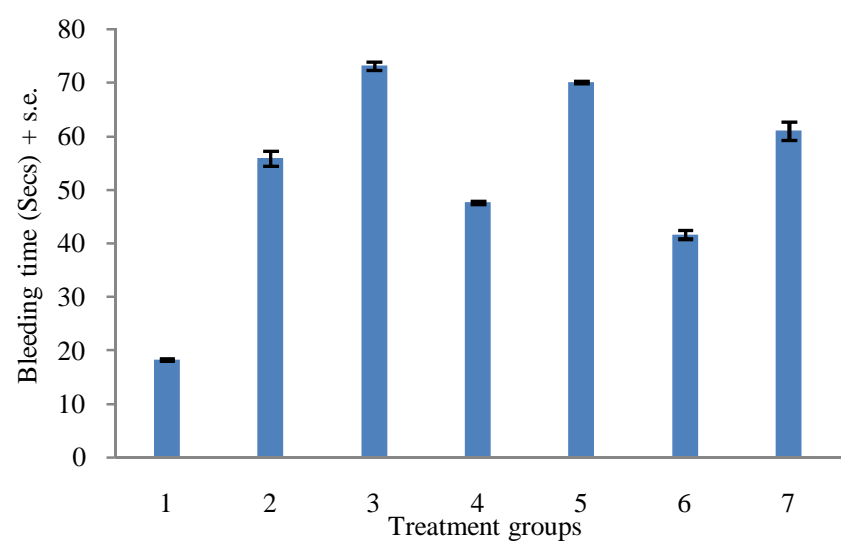

Fig. 1: In vivo effects of Newbouldia laevis leaf extract $(100-200 \mathrm{mg} / \mathrm{kg})$, aspirin $(1-2 \mathrm{mg} / \mathrm{kg})$ and heparin $(0.75-1.5 \mathrm{mg} / \mathrm{kg})$ on bleeding time in rabbits. Values are means \pm S.E. $(\mathrm{n}=5) .{ }^{* *} \mathrm{p}<0.01$ compared to vehicle-treated group. ${ }^{+} \mathrm{p}<0.05$ significant differences between dose levels

\section{Thrombin-induced clotting time assay (TT)}

A comparison of the in vitro anticoagulant activity of NLMLE with heparin in thrombin-induced clotting time is presented in Table 2. The leaf extract of $N$. laevis significantly $(\mathrm{p}<0.01)$ potentiated elevation in thrombin-induced clotting time in a dose dependent manner but at a reduced potency compared to heparin. At 10, 100 and $1000 \mu \mathrm{g} / \mathrm{ml}$, the extract prolonged thrombin-induced clotting time of $40.2 \mathrm{~s}$ produced with buffer to 97.3, 172.3 and $251.4 \mathrm{~s}$ respectively but relative to $280.2,300.8$ and $330.1 \mathrm{~s}$ with heparin at the same concentration. 
Table 2: Comparison of the in vitro activity of Newbouldia laevis extract with heparin in Thrombin-induced clotting time.

\begin{tabular}{lll}
\hline \multicolumn{1}{c}{ Compound/extract } & \multicolumn{1}{c}{$\begin{array}{c}\text { Concentration } \\
(\boldsymbol{\mu g} / \mathbf{m l})\end{array}$} & $\begin{array}{c}\text { Prolongation time } \\
(\mathbf{s})\end{array}$ \\
\hline N. laevis extract & 10 & $97.3 \pm 0.5^{* *}$ \\
N. laevis extract & 100 & $172.3 \pm 0.7^{* *}$ \\
N. laevis extract & 1000 & $251.4 \pm 1.2^{* *}$ \\
Heparin & 10 & $280.2 \pm 0.4^{* *}$ \\
Heparin & 100 & $330.8 \pm 0.6^{* *}$ \\
Heparin & 1000 & $330.1 \pm 0.2^{* *}$ \\
Negative control (buffer) & & 40.2 \\
Normal plasma & - & 15.7 \\
Values are mean \pm SEM $(\mathrm{n}=5) ; * * \mathrm{p}<0.01$ compared to negative control \\
(buffer)
\end{tabular}

\section{DISCUSSION}

The crude leaf extract of $N$. laevis was tolerated by the experimental rats hence; the highest oral test dose $(2000 \mathrm{mg} / \mathrm{kg})$ produced no observable mortality within $72 \mathrm{~h}$ of the investigation. The methanol extract exhibited marked anticoagulant activity and this could be the reason for the prolonged in vitro time of blood clotting observed with the test samples (Table 1). The in vivo effects of the extract in relation to that of aspirin and heparin resulted in increased bleeding times (Figure 1). The high doses $(100-200 \mathrm{mg} / \mathrm{kg})$ of the extract however, exhibited the most profound bleeding effect compared to either aspirin or heparin. The extract displayed a comparatively lower potency compared to heparin in thrombin-induced clotting time. This was demonstrated when $1000 \mu \mathrm{g} / \mathrm{ml}$ of the extract produced clotting at $251.4 \pm 1.2 \mathrm{~s}$ but heparin at the same concentration prolonged the clotting time to $330.1 \pm 0.2 \mathrm{~s}$. This is quite logical since heparin is a pure compound while the extract is crude with many contaminants. The mechanism by which the extract mediated its anticoagulant activity is not fully understood but chelating agents, heparin, aspirin and vitamin $\mathrm{K}$ antagonists are known to interfere with blood clotting processes using diverse mechanisms.

Chelating agents including trisodium citrate, sodium oxalate and ethylene diaminetetraacetic acid (EDTA) bind with calcium ions and render them unavailable to facilitate coagulation reactions (Rowsell, 1969). Heparin, contained in mast cells is released into circulation when mast cells degranulate during inflammation. Heparin can inhibit clotting factor IXa, XIa and thrombin but its action on factor Xa accounts for its potency as an anticoagulant (Melvin, 1977).

Heparin can inhibit both the generation of thrombin and also the formed thrombin. Non-steroidal anti-inflammatory drugs including aspirin inhibit cyclooxygenase enzymes (COX) of prostaglandin and thromboxane $\mathrm{A}_{2}\left(\mathrm{TXA}_{2}\right)$ biosynthesis from arachidonic acid. Repeated doses of aspirin can irreversibly inhibit COX-1-dependent $\mathrm{TXA}_{2}$ formation. Thromboxane induce platelet aggregation and also acts as amplification signal for other, more potent platelet agonists such as thrombin and adenosine diphosphate (Brunton et al., 2008). The synthesis of clotting factors II, VII, IX and X in the liver depends on adequate amounts of vitamin K. Coumarin and inadedione group of oral anticoagulant drugs antagonizes the synthesis of non functional forms of coagulant proteins and thereby prevents blood clot formation (Schneeweiss et al., 2012). The N. laevis leaf extract prolonged thrombin-induced clotting time suggesting that its anticoagulant effect might be linked to its ability to inhibit thrombin generation and fibrin formation. The phytochemical screening revealed the presence of reducing sugars, alkaloids, tannins, flavonoids, resin, phenols, proteins, and acid compounds in the crude extract. A bioactive phyto-constituent may be responsible for the observed anticoagulant activities of the leaf extract.

\section{CONCLUSION}

The prolonged in vitro time of blood clotting coupled with in vivo effects that culminated in increased bleeding times and the potentiated thrombin-induced clotting time with the extract demonstrated that the methanol leaf extract of $N$. laevis possesses pharmacologically active anticoagulant principles that could be isolated and evaluated for clinical and physiological applications.

\section{REFERENCES}

Afonne O.J., Orisakwe O.E., Obi E., Orish C. and Akumba D.D. Some Pharmacological properties of Synclisia scabrida III. Indian J. Pharmacol. 2000; 32: 239-241.

Ahmed S.G. and Orakah J.A. Cellular changes in stored whole blood and the implication on efficacy of transfusion therapy in Nigeria. The Internet Journal of Third World Medicine. 2009; 8(2). Available at: http://www.ispub.com/journal/the-internet-journal-of-thirdworldmedicine/ volume-8-number-2/cellular-changes-in-stored-wholeblood-andtheimplication-on-efficacy-of-transfusion-therapy-innigeria.html (Accessed July 25, 2013)

Akunyili D.N. Anticonvulsant activity of the Ethanolic Extract of Newbouldia laevis, a paper delivered at the $2^{\text {nd }}$ National Association for the Advancement of Psychoanalysis (NAAP) conference held in Zaria, Nigeria in 2000. 2000; 155-158.

Arbonnier M. Trees and Shrubs of West Africa Dry Zones (5th Ed.). Editions Quae, Versailles, France. 2004; pp. 194.

Bafor E. and Sanni U. Uterine contractile effects of the aqueous and ethanol leaf extracts of Newbouldia laevis (Bignoniaceae) in vitro. Indian J. Pharm. Sc. 2009; 71 (2): 124-127.

Brunton L., Parker K., Blumenthal D. and Buxton I. Eds. Goodman \& Gilman's Manual of Pharmacology and Therapeutics. Mc Graw Hill Medical, New York. 2008; pp. 429-430.

Cheesbrough M. 2000. District Laboratory Practice in Tropical Countries (Part 2). Cambridge University Press, London. pp. 297-298.

Dong B., Jirong Y., Liu G. et al. Thrombolytic therapy for pulmonary embolism. Cochrane Database System Rev. 2006: 1998; CD004437.

Donnan G.A., Fisher M., Macleod M. and Davis S. M. Secondary prevention of stroke. Stroke Lancet. 2008; 371: 1612-1623.

Deitelzweig S., Amin A., Jing Y., Makenbaeva D., Wielderkehr D., Lin J. and Graham J. Medical cost reductions associated with the usage of novel oral anticoagulants vs warfarin among atrial fibrillation patients, based on the RE-LY, ROCKET-AF, and ARISTOTLE trials. J. Med. Econ. 2012; 15 (4): 776-85.

Elg M., Carlson S. and Gustafsson D. Effects of agents used to treat bleeding disorders on bleeding time prolonged by a very high dose of direct thrombin inhibitor in anesthetized rats and rabbits. Thrombosis Res. 2001; 101: 159-170.

Fenk C.J., Kaufman N. and Gerbig D.G. Protein detection and measurement. J. Chem. Educ. 2007; 84: 1676-1678.

Forscher C.A., Sussman I.I. and Friedman E.W. Pseudothrombocytopenia masking true thrombocytopenia. Am. J. Hematol. 1985; 18: 313-17. 
Gofner S., Wolfender J.L., Nianya M. and Hostesttmann K. Phenylpropanoid glycosides from Newbouldia laevis roots. Phytochemistry. 1997; 44 (4): 687-690.

Handoll H.H.G., Farrar M.J., McBirnie J., Tytherleigh-Strong G.M., Milne A.A. and Gillespie W.J. Heparin, low molecular weight heparin and physical methods for preventing deep vein thrombosis and pulmonary embolism following surgery for hip fractures. Cochrane Database Syst. Rev. 2002; 2: CD000305-CD000305.

Helsinki Declaration. Animal research, rules and guidelines, adopted by the $18^{\text {th }}$ World Medical Assembly, Helsinki, Finland, June, 1964.

Holbrook A.M., Pereira J.A., Labiris R., McDonald H., Douketis J.D., Crowther M. and Wells P.S. Systemic overview of warfarin and its drug and food interactions. Arch. Intern. Med. 2005; 165 (10): 1095-106.

Koffuor G. A. and Amoateng P. Antioxidant and anticoagulant properties of Phyllanthus fraternus GL Webster (Family: Euphorbiaceae). Journal of Pharmacology and Toxicology. 2011; 6(7): 624-636.

Lipp G., Salvaqno G.L., Solero G.P., Franchini M. and Guidi G.C. Stability of blood cell counts haematological parameters and reticulocyte indexes on the Advia A120 haematologic analyzer. J. Clin. Med. 2005; 146 (6): 333-340.

McCardel B.R., Lachiewicz P.F. and Jones K. Aspirin prophylaxis and surveillance of pulmonary embolism and deep vein thrombosis in total hip arthroplasty. J. Arthroplasty 1990; 5: 181-185.

Melvin J.S. Ed. Duke's Physiology of Domestic animals $\left(9^{\text {th }}\right.$ Ed.). CBS Publishers \& Distributors PVT Ltd., New Delhi, India. 1977; pp.36-46.

Mousa S.A. Antithrombic effects of naturally derived products on coagulation and platelet function. Methods Mol. Biol. 2010; 663: 22940 .

Mushore J. and Matuvhumye T. Antibacterial properties of Magnifera indica on Staphilococcus aureus. Afr. J. Clin. Exper. Microbiol. 2013; 14 (2): 67-74.

NIH (National Institute of Health Publication No. 85-23, Revised 1985): Guide for the Care and Use of Laboratory Animals
Potpara T.S., Polovina M.M., Licina M.M., Stojanovic R.M., Prostran M.S. and Lip, G.Y. Novel oral anticoagulants for stroke prevention in atrial fibrillation: focus on apixaban. Adv. Ther. 2012; 29 (6): 491-507.

Rowsell H.C. Blood coagulation and haemorrhagic disorders. In: Medway, W., Prier, J.E. and Wilkinson, J.E. (Eds.). A textbook of Veterinary Clinical Pathology. Williams \& Wilkins, Baltimore. 1969; pp. 247-81.

Tattelman E. Health effects of garlic. Am. Fam. Physician. 2005; 72 (01): 103-106.

Tohgi H., Konno S., Tamura K., Kimura B. and Kawano K. Effects of low-to-high doses of aspirin on platelet aggregability and metabolites of thromboxane A2 and prostacycline. Stroke. 1992; 23: 14001403.

Trease G.E. and Evans W.C. Pharmacognosy (12 ${ }^{\text {th }}$ Ed.). Baillere Tindall, London. 1989; pp. 687-689.

Schneeweiss S., Gagne J.J., Patrick A.R., Choudhry N.K. and Avom J. Comparative efficacy and safety of new oral anticoagulants in patients with atrial fibrillation. Cir. Cardiovasc. Qual Outcomes. 2012; 5 (4): $480-6$.

Webster C. Quick Look Series in Veterinary Clinical Pharmacology. Teton New media Wyoming, USA. 2001; pp. 124-125.

\section{How to cite this article:}

Chinaka O. Nwaehujor, Rita I. Udegbunam, Julius O. Ode, Stella A. Madubuike. Antithrombotic activities of Newbouldia laevis (P. Beauv) seem. ex Bureau leaves. J App Pharm Sci, 2015; 5(05): 075-079. 